\title{
Ceramic-Based 3D Printed Supports for Photocatalytic Treatment of Wastewater
}

\author{
Lorena Hernández-Afonso, ${ }^{1}$ Ricardo Fernández-González, ${ }^{1}$ \\ Pedro Esparza, ${ }^{1}$ M. Emma Borges, ${ }^{2}$ Selene Díaz González, ${ }^{1}$ \\ Jesús Canales-Vázquez, ${ }^{3}$ and Juan Carlos Ruiz-Morales ${ }^{1}$
}

\begin{abstract}
${ }^{1}$ Chemistry Department, University of La Laguna, San Cristóbal de La Laguna, Tenerife, 38200 Canary Islands, Spain
${ }^{2}$ Chemical Engineering Department, University of La Laguna, San Cristóbal de La Laguna, Tenerife, 38200 Canary Islands, Spain

${ }^{3}$ Instituto de Energías Renovables, Print3D Solutions, University of Castilla-La Mancha, 02006 Albacete, Spain
\end{abstract}

Correspondence should be addressed to Juan Carlos Ruiz-Morales; jcruiz@ull.edu.es

Received 21 March 2017; Accepted 20 April 2017; Published 10 July 2017

Academic Editor: Roberto Comparelli

Copyright (C) 2017 Lorena Hernández-Afonso et al. This is an open access article distributed under the Creative Commons Attribution License, which permits unrestricted use, distribution, and reproduction in any medium, provided the original work is properly cited.

\begin{abstract}
3D printing technology has become a powerful tool to produce 3D structures in any type of materials. In this work, 3D printing technology is used to produce $3 \mathrm{D}$ porous structures in $\mathrm{CaSO}_{4}$ which can be later activated with an appropriate photocatalyst. $\mathrm{TiO}_{2}$ was selected as an ideal photocatalyst producing activated 3D structures which can be used to study their effectiveness in the degradation of pollutants in wastewater. Methylene blue was used as a model molecule in these studies. The photocatalytic studies showed that $\mathrm{TiO}_{2}$-activated 3D structures using nanoparticles of $\mathrm{SiO}_{2}$ in the process produce more than $50 \%$ of conversion of methylene blue in just $1 \mathrm{~h}$ of irradiation and almost $90 \%$ in $5 \mathrm{~h}$.
\end{abstract}

\section{Introduction}

Global warming, energy crisis, and pollution are serious concerns affecting both the human health and environment. The environmental pollution includes a wide range of hazardous chemicals which are harmful even at extremely low concentrations.

The common treatment of these pollutants involves the use of pyrolytic methods which consume large amounts of fossil fuels producing elevated levels of $\mathrm{CO}_{2}$ and thus contributing again to climate change and energy crisis.

Another severe issue [1-3] is water pollution from emerging contaminants (ECs) such as endocrine disrupting chemicals, pharmaceuticals, and personal care products even at trace levels. Some adverse potential effects caused by ECs are water toxicity, resistance development in pathogenic bacteria, genotoxicity, and endocrine disruption [4-6].

Wastewater treatment plants are not designed to remove low concentrations of synthetic pollutants such as pharmaceuticals and hence alternatives such us the Advanced
Oxidation Technology (AOT) have been used to solve this environmental problem $[7,8]$.

Heterogeneous photocatalytic processes constitute one of the most important AOTs and are based on the oxidation of polluting compounds which can be found in air or water by means of a reaction occurring on a semiconductor catalytic surface activated by light with a specific wavelength.

$\mathrm{TiO}_{2}$ is the most investigated semiconductor catalyst particularly because of its great potential in the treatment of environmental pollution [9] and it is chemically stable, nontoxic, and inexpensive [10-12]. However, $\mathrm{TiO}_{2}$ has an important disadvantage as it is usually commercially available as powder and, therefore, a posttreatment separation stage is needed $[13,14]$ and hence it would be highly desirable to have the possibility of supporting the $\mathrm{TiO}_{2}$ active phase on other structured inorganic materials.

In this sense, a new exciting approach for the production of structured materials on demand may be the use of a 3D printing (3DP) system. Until the past few years, this type of technology has been restricted to medium- and big-sized 


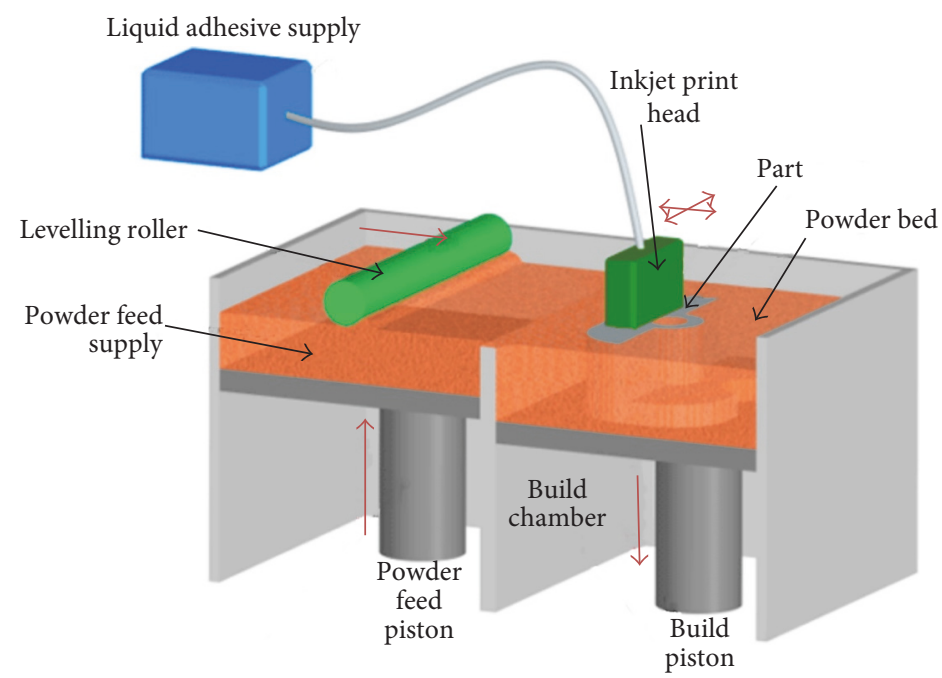

FIgURE 1: Indirect Inject Print (IIP) is a layer-by-layer process of depositing liquid binder onto thin layers of powder to create a 3D object [17].

companies devoted to the fabrication of prototypes. Nowadays, they are increasingly available for small businesses (research [15]) and even for direct manufacturing. 3D micro fabrication remained a challenge until the introduction of free-forming fabrication (FFF) technology. Free-forming fabrication is any fabrication technology that fabricates $3 \mathrm{D}$ complex structures by assembling small elements together and usually starts with a computer aided design (CAD) model. FFF includes, but is not limited to, rapid prototyping, 3D printing, and direct writing for macro scale fabrication [16].

A digital model of the object is created in a computer. Using adequate software, the user may control several relevant parameters such as the number of layers which are piled up to generate the full item depending on the resolution required, thickness of the layers, and porosity. In the second step, each digital layer is printed in an appropriate substrate. Different 3D printing techniques can be selected depending on the material required and the way to fuse layers together. One of the 3D printing options is the Indirect Inject Print, where a powder is spread from a well (Figure 1), levelling it to produce a thin layer. Then the printer heads will dispense a thin layer of a binder in the required pattern of the cross section. When the layer is finished, the "build tray" will be lowered by a fraction of a millimetre, typically between 10 and $100 \mu$ and then the process is repeated again for the next cross section. Finally, after printing the whole 3D structure, the loose powder is blown away with compressed air, revealing the full structure [16].

This type of technology has the potential to allow the fabrication of monolithic porous structures that can be covered with a layer of catalytically active material such as $\mathrm{TiO}_{2}$ [18]. Calcium sulphate hemihydrate $\left(\mathrm{CaSO}_{4} \cdot 1 / 2 \mathrm{H}_{2} \mathrm{O}\right)$ was one of the first materials to be used for IIP. It can be wetted using a commercially formulated binder ( $98 \%$ content water) and then forms a gypsum paste $\left(\mathrm{CaSO}_{4} \cdot 2 \mathrm{H}_{2} \mathrm{O}\right)$ by activating self-hydration [19] which can be used to produce 3D porous supporting structures.
The aim of this study is to verify that the 3D printing technology can be used to produce porous monolithic structures of calcium sulphate which can be then activated with commercial $\mathrm{TiO}_{2}$ photocatalyst (Degussa P25) through an impregnation process. The whole $3 \mathrm{D}$ activated system will be tested in a fixed-bed photoreactor to verify the potential use of these heterostructures for removing wastewater contaminants using methylene blue (MB) as a model molecule.

\section{Materials and Methods}

The activity of the $\mathrm{TiO}_{2}$ photocatalyst supported over a 3D printed ceramic structure was studied evaluating the photodegradation of methylene blue (Sigma-Aldrich) as a model molecule for wastewater treatments. The photocatalytically active material, $\mathrm{TiO}_{2}$ (Degussa P25, Evonik Industries), was examined by X-ray diffraction (XRD) in order to obtain the percentage of anatase and rutile phase. Nitrogen adsorptiondesorption porosimetry and mercury porosimetry techniques were used to study its specific surface area and textural properties [20]. $\mathrm{TiO}_{2}$ (Degussa P25) was mainly composed by the photocatalytically active anatase phase, $81 \%(\mathrm{wt})$. The textural parameters of $\mathrm{TiO}_{2}$ powder were $51.1 \mathrm{~m}^{2} / \mathrm{g}$ of BET specific area, a total pore area of $63.7 \mathrm{~m}^{2} / \mathrm{g}$ with $92.5 \%$ of porosity, and a density of $2.58 \mathrm{~g} / \mathrm{ml}$.

2.1. 3D Printing Structures. The materials used in the 3D printing process were calcium sulphate hemihydrate (Visijet PXL Core, from S.A.T.ÉLITE) and a water-based binder (Visijet Clear, from S.A.T.ÉLITE). These materials were used in a 3D printer (ProJet $^{\circledR} 360$, from S.A.T.ÉLITE), with a 300 $\times 450$ dpi resolution and layer thickness of $0.1 \mathrm{~mm}$.

First, the structure is digitally designed using free software Tinkercad [22] and the corresponding digital model is saved as a stl file and then sent to the 3D printer. During the three printing processes (Figures 2(a)-2(d)), a roller spread a thin powder layer from the feed area to the build area 


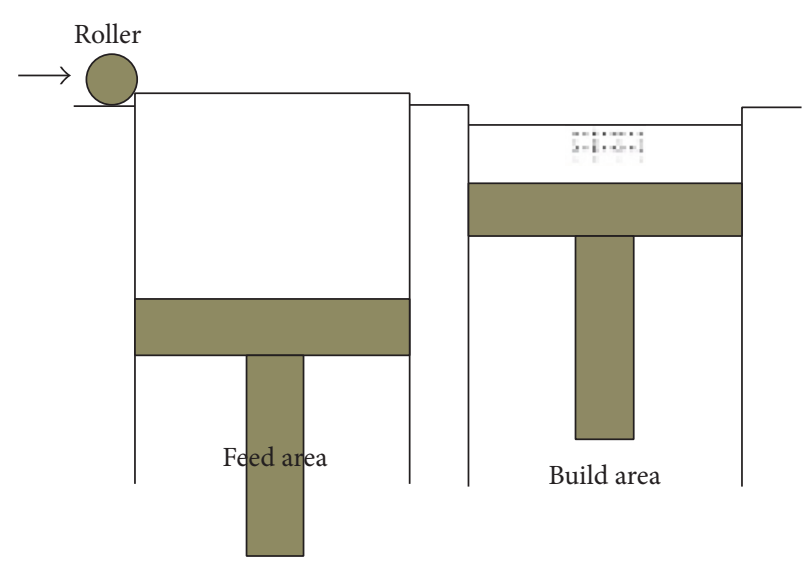

(a)

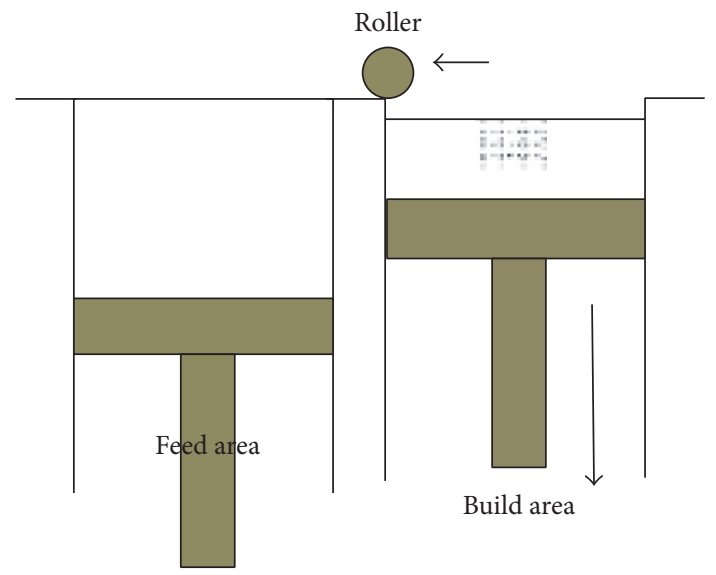

(c)

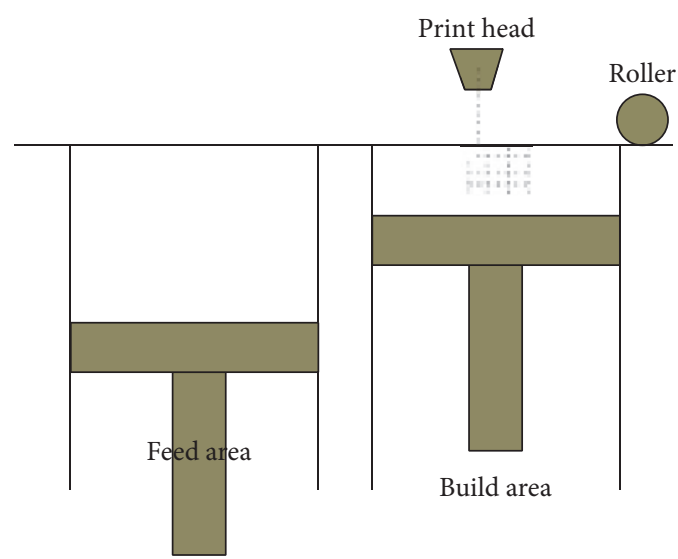

(b)

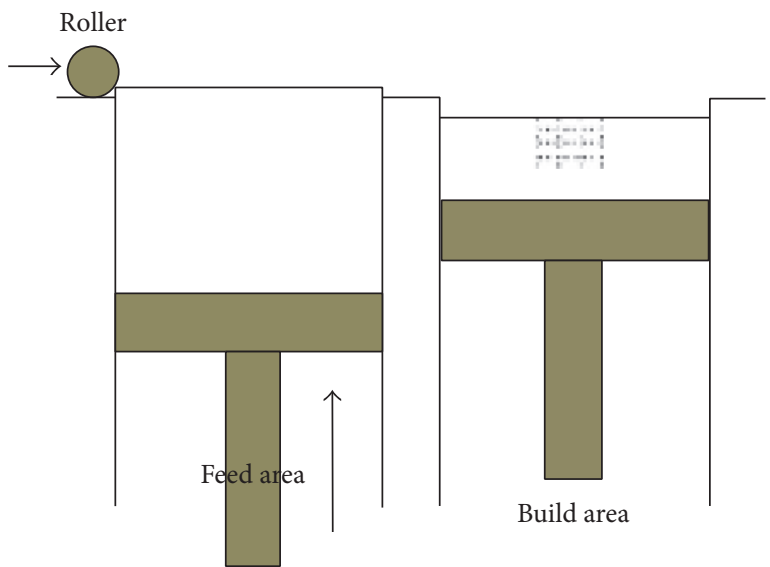

(d)

FIGURE 2: 3DP process scheme. (a) The roller spreads a thin layer of powder from the feed area to the build area. (b) The print head injects binder droplets on the powder bed. (c) After printing a layer, the roller returns to the feed area. (d) Powder in the feed area is raised, while that in the build area is lowered. The roller then spreads another layer of powder [21].

and then the print head deposits binder droplets selectively within the build area. When the first layer is printed, the roller returns to the feed area, spreading another powder layer to the build area. This procedure is repeated until the fabrication of the whole 3D structure is completed [21].

Following this procedure, several microtubes of ceramic supporting structures were 3D printed (Figures 3(a) and $3(b)$ ), and several small rectangular and square pieces of $2 \times$ $2 \mathrm{~cm}$ were also $3 \mathrm{D}$ printed as testing samples in mechanical stability versus temperature studies (Figures 3(c) and 3(d)). $150^{\circ} \mathrm{C}$ was the selected prefiring temperature to give enough mechanical stability for withstanding the conditions of the impregnation process.

\subsection{Improving the Mechanical Stability of the $3 D$ Printed} Structures. Two routes were followed to impregnate the 3D structures with another inorganic material enhancing the mechanical stability up to $1200^{\circ} \mathrm{C}$. The $3 \mathrm{D}$ printed samples were previously fired at $150^{\circ} \mathrm{C}$ for $2 \mathrm{~h}$ to improve the mechanical stability in aqueous solution needed for the impregnation processes. (i) Route 1. Impregnation was done with an aqueous dispersion of alumina $\left(\mathrm{Al}_{2} \mathrm{O}_{3}\right.$, Almatis $\left.\mathrm{GmbH}\right)$ using Dolapix CE64 (Zschimmer \& Schwarz) as dispersant. Several ratios of the components and impregnation times (Table 1) were considered to optimize the process. The impregnation times were also optimized ranging from $10 \mathrm{~s}$ up to $30 \mathrm{~min}$. The soimpregnated samples were left to dry for $45 \mathrm{~min}$ under $70^{\circ} \mathrm{C}$ and then were finally fired at $1200^{\circ} \mathrm{C}$ for $4 \mathrm{~h}$ with heating and cooling ramp rates of $5^{\circ} \mathrm{C} / \mathrm{min}$ (Figure $4(\mathrm{a})$ ).

(ii) Route 2. Impregnation was done with an aqueous solution of Ludox ${ }^{\circledR}$ AS-30 colloidal silica (Sigma-Aldrich). As in the previous method, the printed $3 \mathrm{D}$ structures were initially fired at $150^{\circ} \mathrm{C}$ for $2 \mathrm{~h}$. After that, the specimens were impregnated in Ludox $(1.1 \mathrm{~g})$ and then fired at $600^{\circ} \mathrm{C}$ for $2 \mathrm{~h}$, with heating and cooling ramp rates of $5^{\circ} \mathrm{C} / \mathrm{min}$ (Figure 4(b)); this step is performed twice.

2.3. Photocatalytic Studies. The methylene blue (MB) photodegradation process with the activated $3 \mathrm{D}$ printed structures (A3DS) was carried out in a fixed-bed photoreactor system 
TABLE 1: Ratio of components and impregnation times used in the optimization of the impregnation process of $3 \mathrm{D}$ structures with $\mathrm{Al}_{2} \mathrm{O}_{3}$.

\begin{tabular}{lcccc}
\hline Procedure & $\mathrm{Al}_{2} \mathrm{O}_{3}(\mathrm{~g})$ & Water $(\mathrm{g})$ & Dolapix $(\mathrm{g})$ & Impregnation times $(\mathrm{s})$ \\
\hline 1 & 30,0 & 8,39 & 0,161 & $10,20,30,60,300,600$, and 1800 \\
2 & 30,0 & 16,2 & 0,423 & 0,644 \\
3
\end{tabular}

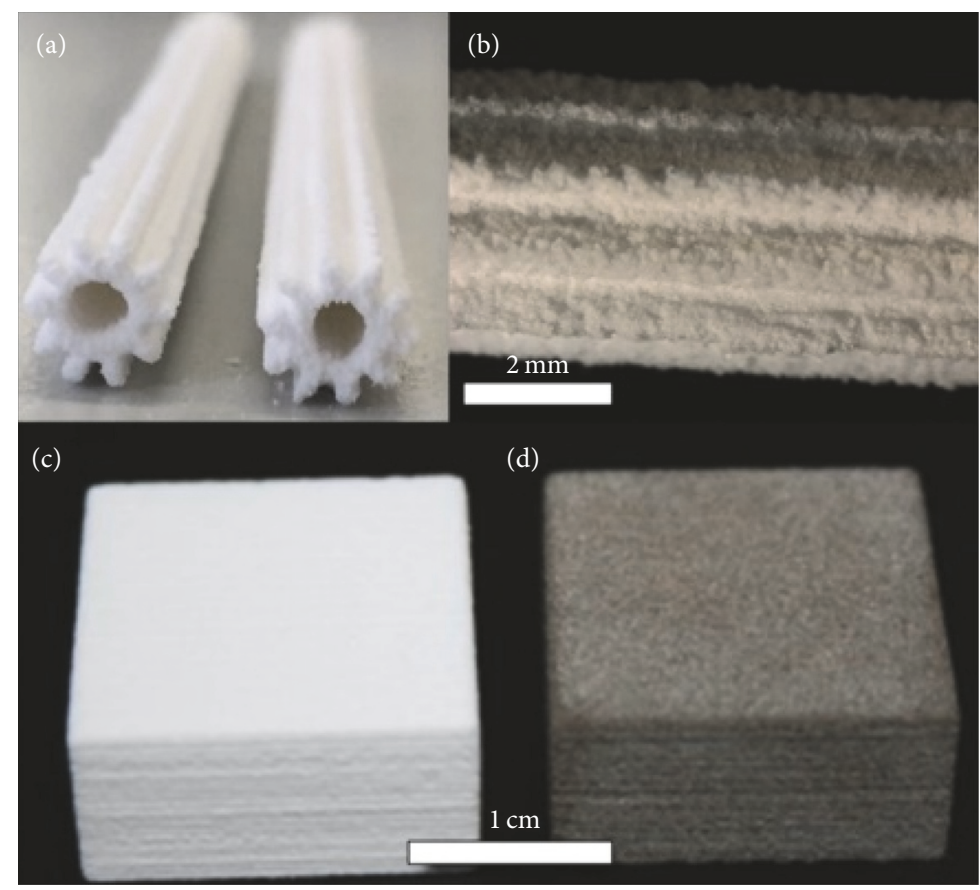

Figure 3: ((a) and (b)) 3D printed supporting structures in $\mathrm{CaSO}_{4}$. (c) 3D printed square testing pieces in the green state and (d) after firing at $250^{\circ} \mathrm{C}$ for $3 \mathrm{~h}$.

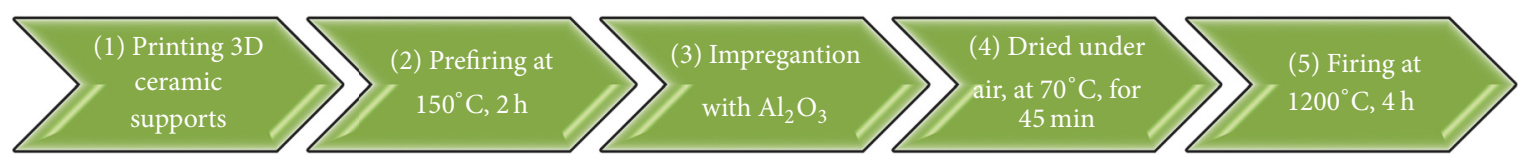

(a)

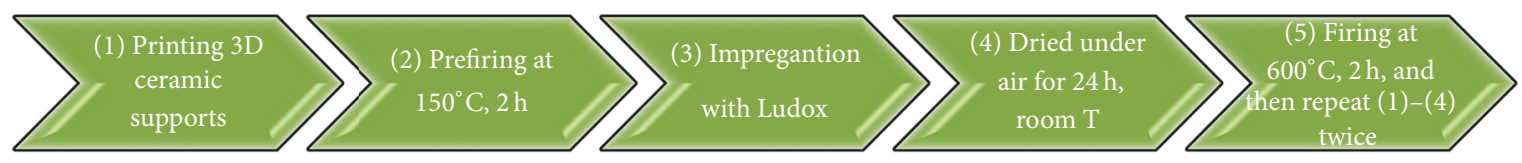

(b)

FIGURE 4: Schemes for improving the mechanical stability of 3D printed supporting structures using two alternative impregnation routes: (a) route 1 with $\mathrm{Al}_{2} \mathrm{O}_{3}$ and (b) route 2 with Ludox dispersions.

(Figure 5(a)). A3DS were placed in the photocatalytic reactor $(18 \mathrm{~cm}$ length and $0.6 \mathrm{~cm}$ internal diameter) (Figure $5(\mathrm{~b})$ ), and a solar radiation sodium vapor lamp (Philips, model $400-W G / 92 / 2$ ), placed at a distance of $50 \mathrm{~cm}$ from the fixedbed reactor, was used as light source (total radiation flux measured on the fixed-bed surface was $160 \mathrm{~mW} / \mathrm{cm}^{2}$ ). MB solution in water $(20 \mathrm{ppm})$ was introduced in a $250 \mathrm{ml}$ wastewater photoreactor tank (Figure 5(c)), keeping the temperature constant at $25^{\circ} \mathrm{C}$. The $\mathrm{MB}$ solution was recirculated along the system using a peristaltic pump (Watson-Marlow, model 302S). Several samples were taken during several hours of irradiation time and they were analyzed by UV-Vis spectrophotometry in order to follow the evolution of MB concentration into the reactor. Moreover, MB photolysis (with light source and without photocatalyst) and $\mathrm{MB}$ adsorption onto A3DS (with photocatalyst and without light source) experiments were developed in order to evaluate its contribution to the global wastewater decontamination process. 


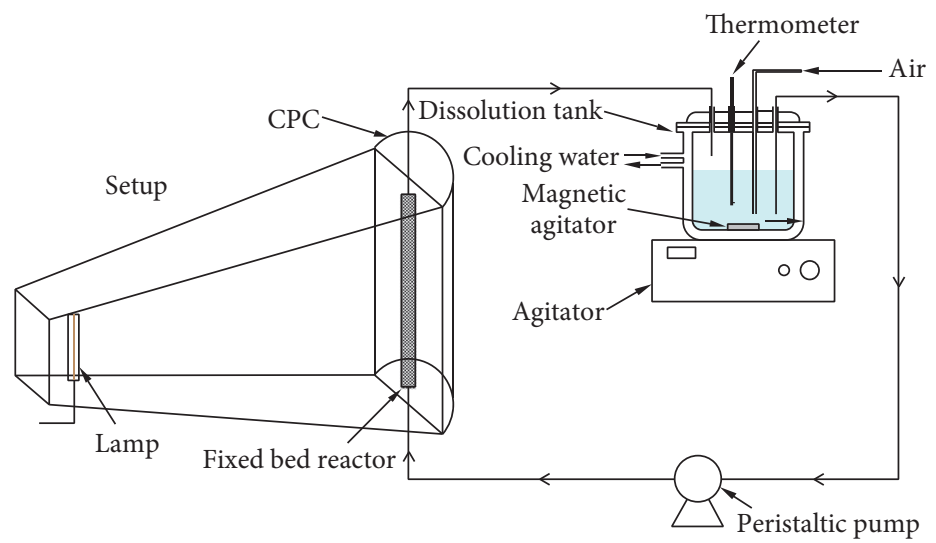

(a)

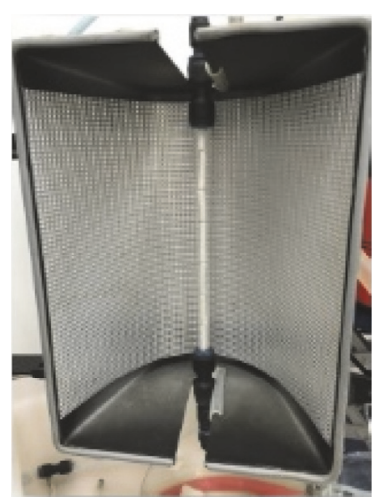

(b)

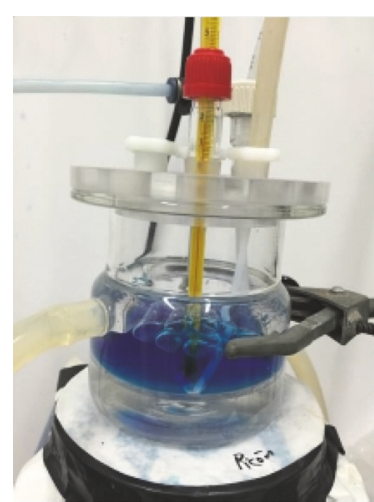

(c)

FIGURE 5: (a) Fixed-bed photoreactor scheme. (b) Fixed-bed reactor. (c) Wastewater photoreactor tank.

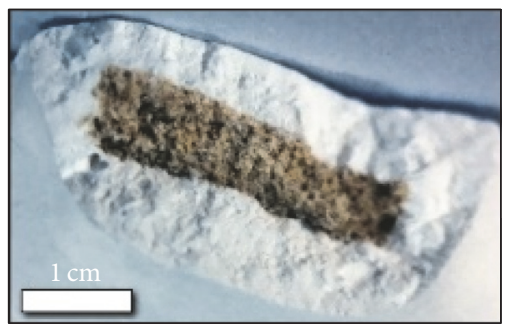

(a)

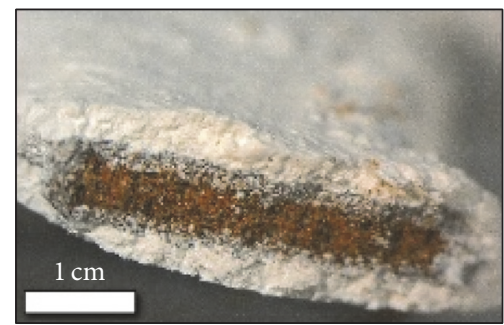

(b)

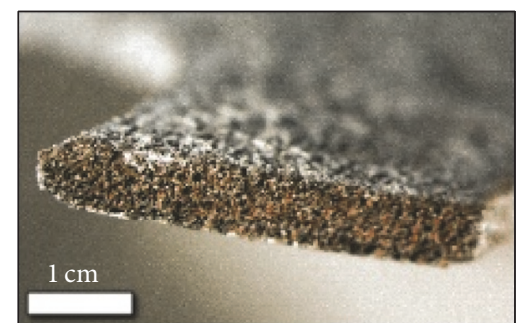

(c)

FIGURE 6: Optical images of impregnated 3D structures with dispersions of $\mathrm{Al}_{2} \mathrm{O}_{3}$, using an $\mathrm{Al}_{2} \mathrm{O}_{3}$ concentration of (a) $0.77 \mathrm{~g} / \mathrm{ml}$, (b) $0.65 \mathrm{~g} / \mathrm{ml}$, and $(\mathrm{c}) 0.47 \mathrm{~g} / \mathrm{ml}$.

2.4. Microstructural Characterization. The morphologies of the $3 \mathrm{D}$ structured samples in the green and sintered states were examined using a stereomicroscope Leica Zoom 2000 (Leica Microsystems, Inc.) and a scanning electron microscope (SEM) (model Jeol LTD, JSM-6300) combined with energy dispersive spectroscopy (EDS). For SEM studies, all samples were covered with a thin film of sputtered silver to avoid charging problems and to obtain better image definition.

\section{Results and Discussion}

As commented in the text, before the activation of the $3 \mathrm{D}$ supporting structures, the mechanical stability of the structures must be improved and we can use two routes.

3.1. Route 1: Impregnation with Alumina. Several impregnation studies (Table 1) with alumina dispersions were tested. The impregnation time was also optimized and it was concluded that no significant differences were observed between samples impregnated for $30 \mathrm{~s}$ or $5 \mathrm{~min}$ and, hence, $30 \mathrm{~s}$ was the time used in all the procedures tested. Procedure 1 (Table 1) produces a $0.8 \mathrm{~mm}$ thick external covering layer of $\mathrm{Al}_{2} \mathrm{O}_{3}$ over the $3 \mathrm{D}$ structure; however, the porous $3 \mathrm{D}$ structure seems to be alumina-free (Figure 6(a)), and hence the inner structure will collapse at high temperature.
Procedure 2 (Table 1) produces two types of covering: an external layer of $\mathrm{Al}_{2} \mathrm{O}_{3}$, as in the first case, and an additional inner impregnated layer covering about $70 \%$ of the $3 \mathrm{D}$ porous structure (Figure 6(b)). The combination of both layers is ideal for improved mechanical stability.

And finally in procedure 3 (Table 1) with a more diluted dispersion, only the internal layer was observed (Figure 6(c)), which is not enough to provide mechanical stability at high temperatures and hence procedure 2 was used to test all the $3 \mathrm{D}$ printed structures.

From the SEM images, it is possible to observe a good distribution of $1 \mu \mathrm{m} \mathrm{Al} \mathrm{O}_{2} \mathrm{O}_{3}$ particles in the surface of the covered $3 \mathrm{D}$ structure (Figure $7(\mathrm{a})$ ) and also a good distribution inside of the porous structure (Figures 7(b) and 7(c)). The presence of $\mathrm{Al}_{2} \mathrm{O}_{3}$ is negligible in the inner part of the $3 \mathrm{D}$ porous structure (Figure $7(\mathrm{~d})$ ), with a value of $0,6 \%(\mathrm{wt})$ of $\mathrm{Al}$ shown in the EDX studies compared to $25,1 \%$ (wt) of $\mathrm{Al}$ obtained in the structures impregnated shown in Figures 7(b) and $7(\mathrm{c})$.

Once the 3D printed structures (Figures 3(a) and 3(b)) have been impregnated with $\mathrm{Al}_{2} \mathrm{O}_{3}$ and fired at $1200^{\circ} \mathrm{C}$, an activation process with the photocatalytic material must be performed. A cement-based material was used to fix the $\mathrm{TiO}_{2}$ powder to the $3 \mathrm{D}$ structure producing an A3DS and then 3 photocatalytic experiments were carried to analyze the photocatalytic behavior of the $3 \mathrm{D}-\mathrm{TiO}_{2}$ structure under UV light. 


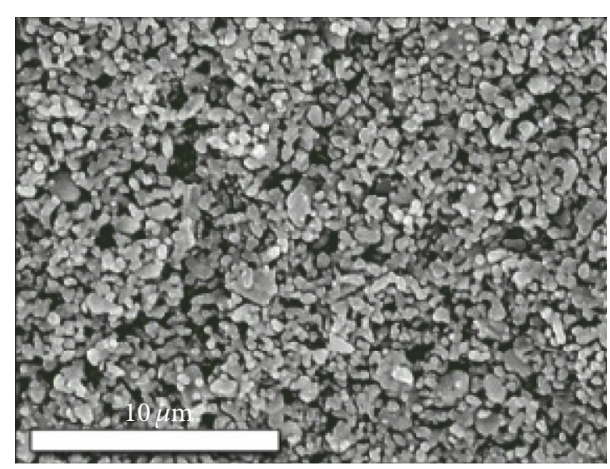

(a)

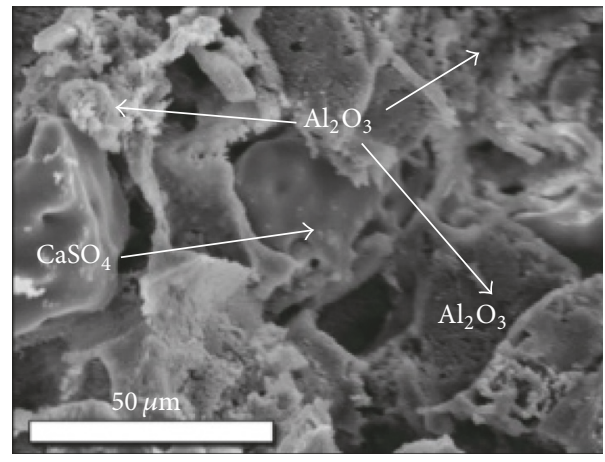

(c)

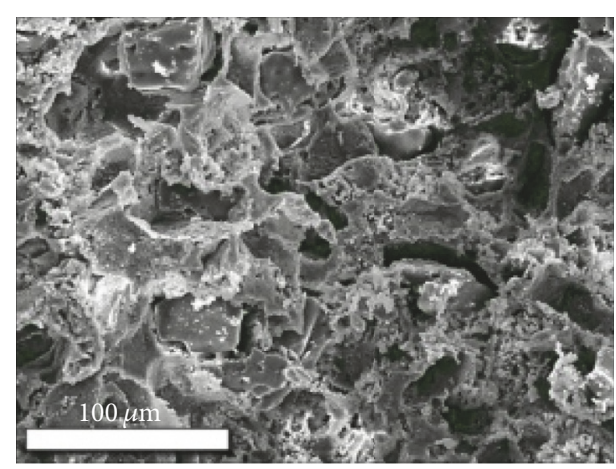

(b)

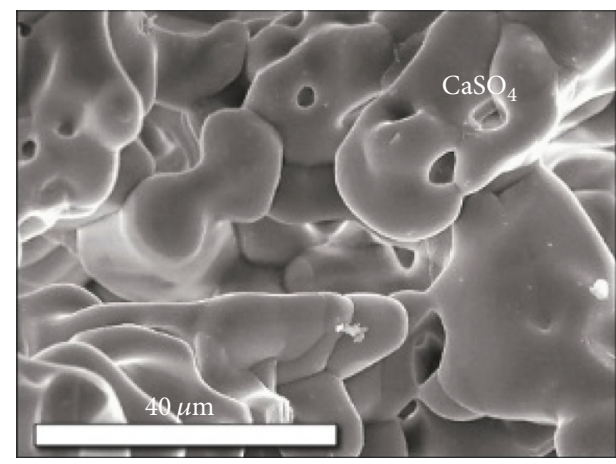

(d)

FIGURE 7: SEM images and EDX data of $\mathrm{Al}_{2} \mathrm{O}_{3}$-impregnated samples following procedure 2 (Table 1) with $30 \mathrm{~s}$ of impregnation time. (a) SEM image of surface of the covered 3D structure. ((b) and (c)) SEM image showing a good distribution of $\mathrm{Al}_{2} \mathrm{O}_{3}$ inside the porous structure. (d) SEM image of the inner part of the supporting $\mathrm{CaSO}_{4}$ porous structure.

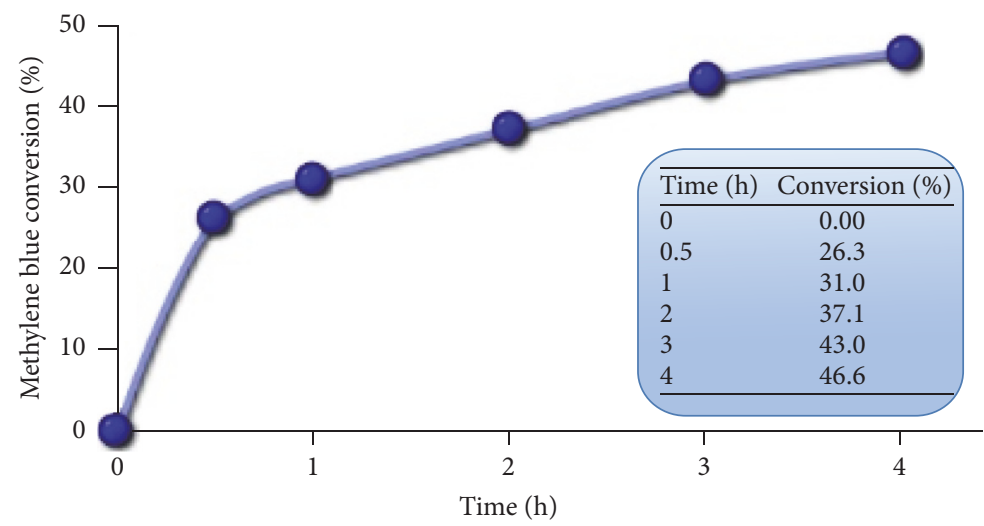

FIGURE 8: Temporal evolution of MB removal during photocatalytic experiments under UV light irradiation using 3DAS fabricated with the first route (Section 2.2).

Figure 8 shows the result of the photocatalytic performance under UV light radiation. The temporal evolution of the concentration of the $\mathrm{MB}$ as contaminant model showed that $\mathrm{MB}$ achieves $46.6 \%$ of conversion with the irradiation time after $4 \mathrm{~h}$. This value proves that the $3 \mathrm{D}$ supporting structure can be effectively used as a support for photocatalytic materials; however, the degree of conversion can be considered relatively low and hence a more optimized structure, possibly with geometries maximizing illumination of the active area and/or improvement of the active area, should be fabricated.

Indeed, just modifying the geometrical surface from plain surface to twisted one produces an enhancement of more than $6 \%$ in the conversion of $\mathrm{MB}$ (Figure 9), that is, from 46.6 to $52.6 \%$, after $4 \mathrm{~h}$.

3.2. Route 2: Impregnation with Silica Nanoparticles (Ludox). Another way to improve the efficiency is to minimize the 


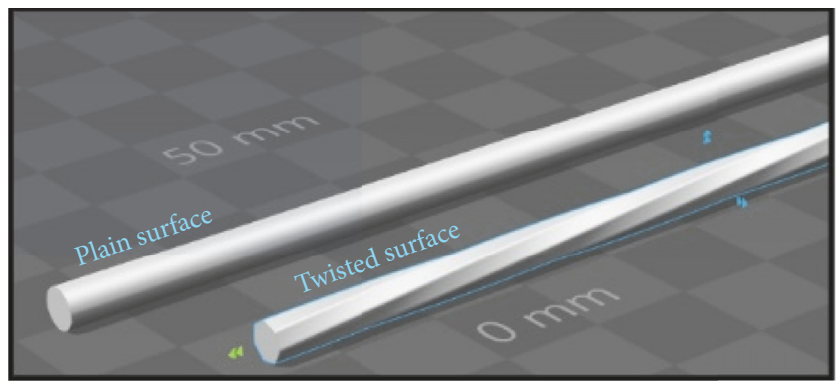

FIGURE 9: Simple 3D models of two types of geometrical surfaces printed to verify how the surface design can modify the photocatalytic experiments.

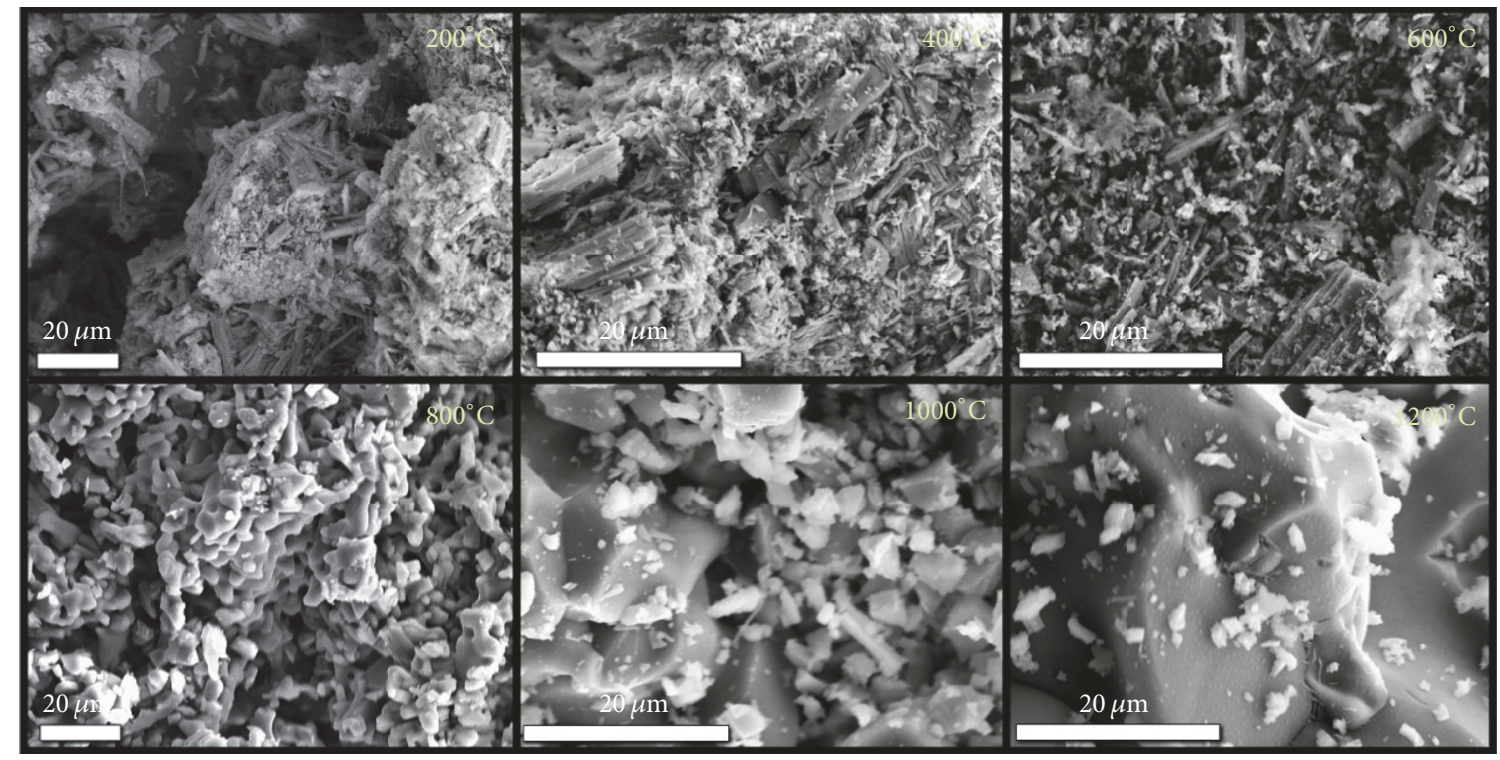

Figure 10: Several 3D printed square pieces of $\mathrm{CaSO}_{4}$ were used to optimize the infiltration process with Ludox. All the samples were infiltrated with a solution of Ludox: water with a ratio of $1: 5$ (wt) for $30 \mathrm{~s}$ and then dried for $10 \mathrm{~min}$ at $70^{\circ} \mathrm{C}$ and finally they were fired at the temperatures shown in the images for $2 \mathrm{~h}$.

distortion of the surface of the 3D printed structures by the impregnated particles. The deposition of microsized $\mathrm{Al}_{2} \mathrm{O}_{3}$ solid particles, previously described, may decrease the available surface area to be covered with the photocatalyst and hence an alternative way to improve the mechanical stability of the 3D printed structures with a minimal distortion of the $3 \mathrm{D}$ surface is required. This can be achieved by using a solution of silica nanoparticles (Ludox) which can be easily infiltrated through the whole porous structure as described in the experimental section, Section 2.2, route 2.

Several tests were performed to optimize the Ludox: water ratio, drying steps, and firing temperature. For example, Figure 10 shows $3 \mathrm{D}$ impregnated samples exhibiting a good distribution of micro/nanoparticles of silica when the final firing temperature was maintained below $600^{\circ} \mathrm{C}$. At higher temperatures, the $3 \mathrm{D}$ porous $\mathrm{CaSO}_{4}$ structure disappears as well as the silica agglomerates; thus the final temperature was kept at $600^{\circ} \mathrm{C}$.

The 3D structures were printed following the second route described in Section 2.2 and then they were activated producing A3DS. In this case, a dispersion of $\mathrm{TiO}_{2}$ was prepared using a Ludox solution in a $1: 1\left(\mathrm{TiO}_{2}: \mathrm{SiO}_{2}\right)$ ratio (weight). The sample was left to dry for $1 \mathrm{~h}$ at $70^{\circ} \mathrm{C}$ and finally fired at $300^{\circ} \mathrm{C}$ for $2 \mathrm{~h}$.

The photoreactor tube was filled with A3DS (Figure 11) and then the photocatalytic performance under UV light radiation was studied. The temporal evolution of the concentration of the MB showed that it achieves $50 \%$ of conversion with the irradiation time in just $1 \mathrm{~h}$, which is more than the conversion obtained with the first route after $4 \mathrm{~h}$. A value close to the $90 \%$ of conversion was obtained after $5 \mathrm{~h}$. This proves again that the $3 \mathrm{D}$ supporting structure can be used as a support of photocatalysts materials and that the optimization of the previous impregnation process can be critical to enhance the activity of the optimized A3DS.

\section{Conclusion}

3D printing technology has been successfully used to create $3 \mathrm{D}$ supporting structures of $\mathrm{CaSO}_{4}$ which can be activated with $\mathrm{TiO}_{2}$ showing photocatalytic activity. 


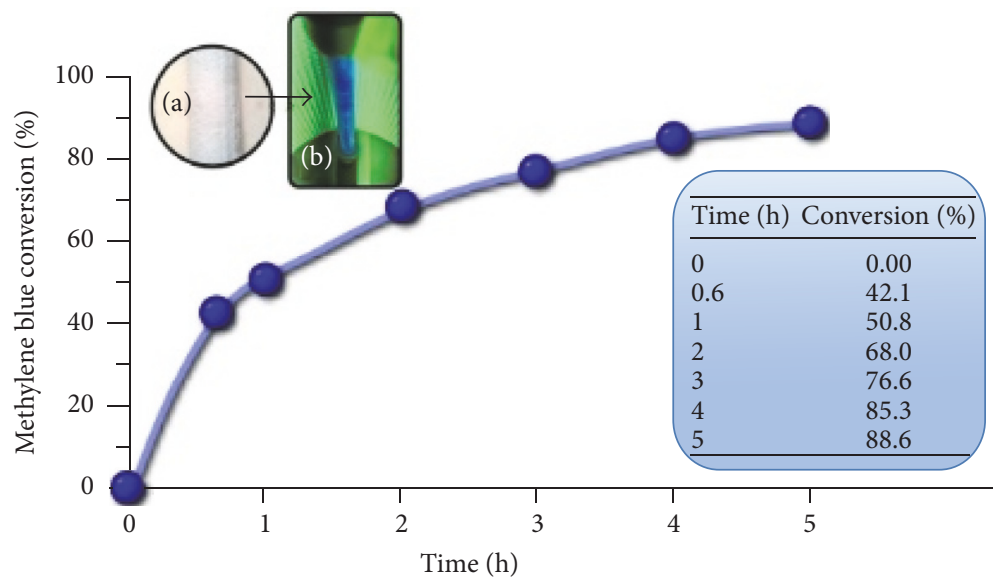

FIGURE 11: Temporal evolution of MB removal during photocatalytic experiments under UV light irradiation using 3D printed supports fabricated with the second route (Section 2.2). The inset image shows (a) the $3 \mathrm{D}$ printed support covered with the photocatalyst $\mathrm{TiO}_{2}$ and (b) the photoreactor filled with the 3D structures and recirculating MB.

Two approaches have been proposed and optimized to enhance the mechanical stability of the $3 \mathrm{D}$ supports up to $1200^{\circ} \mathrm{C}$. In one of them, $\mathrm{Al}_{2} \mathrm{O}_{3}$ is used as a binder of the whole 3D structure; in the other method, a dispersion of nanoparticles of $\mathrm{SiO}_{2}$ (Ludox) acts as a binder.

In both cases, the A3DS show photocatalytic activity for the $\mathrm{MB}$ removal from wastewater, reaching more than $50 \%$ of conversion in just $1 \mathrm{~h}$ of irradiation when using Ludox in the activation process. This approach reaches a high photodegradation rate of about $90 \%$ after $5 \mathrm{~h}$.

The A3DS offer clear advantages for the industrial treatment of wastewater given that the photocatalytic materials remain confined to the packed bed avoiding the need of separating the catalyst from the decontaminated water effluent.

\section{Conflicts of Interest}

The authors declare that there are no conflicts of interest regarding the publication of this paper.

\section{Acknowledgments}

The authors wish to acknowledge the financial support provided by "Ministerio de Economía y Competitividad" (MINECO), "Agencia Estatal de Investigación" (AEI), and "Fondo Europeo de Desarrollo Regional" (FEDER) through the Project ENE2016-74889-C4-2-R.

\section{References}

[1] M. D. Hernando, M. Mezcua, A. R. Fernández-Alba, and D. Barceló, "Environmental risk assessment of pharmaceutical residues in wastewater effluents, surface waters and sediments," Talanta, vol. 69, no. 2, pp. 334-342, 2006.

[2] N. Miranda-García, S. Suárez, B. Sánchez, J. M. Coronado, S. Malato, and M. I. Maldonado, "Photocatalytic degradation of emerging contaminants in municipal wastewater treatment plant effluents using immobilized $\mathrm{TiO}_{2}$ in a solar pilot plant,"
Applied Catalysis B: Environmental, vol. 103, no. 3-4, pp. 294301, 2011.

[3] Z. Zhang, A. Hibberd, and J. L. Zhou, "Analysis of emerging contaminants in sewage effluent and river water: Comparison between spot and passive sampling," Analytica Chimica Acta, vol. 607, no. 1, pp. 37-44, 2008.

[4] N. Miranda-García, M. I. Maldonado, J. M. Coronado, and S. Malato, "Degradation study of 15 emerging contaminants at low concentration by immobilized $\mathrm{TiO}_{2}$ in a pilot plant," Catalysis Today, vol. 151, no. 1-2, pp. 107-113, 2010.

[5] M. Schriks, M. B. Heringa, M. M. E. van der Kooi, P. de Voogt, and A. P. van Wezel, "Toxicological relevance of emerging contaminants for drinking water quality," Water Research, vol. 44, no. 2, pp. 461-476, 2010.

[6] L. Yang, L. E. Yu, and M. B. Ray, "Degradation of paracetamol in aqueous solutions by $\mathrm{TiO}_{2}$ photocatalysis," Water Research, vol. 42, no. 13, pp. 3480-3488, 2008.

[7] M. Pelaez, N. T. Nolan, S. C. Pillai et al., "A review on the visible light active titanium dioxide photocatalysts for environmental applications," Applied Catalysis B: Environmental, vol. 125, pp. 331-349, 2012.

[8] M. A. Sousa, C. Gonçalves, V. J. P. Vilar, R. A. R. Boaventura, and M. F. Alpendurada, "Suspended $\mathrm{TiO} 2$-assisted photocatalytic degradation of emerging contaminants in a municipal WWTP effluent using a solar pilot plant with CPCs," Chemical Engineering Journal, vol. 198-199, pp. 301-309, 2012.

[9] Y.-L. Wei, K.-W. Chen, and H. P. Wang, "Study of chromium modified $\mathrm{TiO}_{2}$ nano catalyst under visible light irradiation," Journal of Nanoscience and Nanotechnology, vol. 10, no. 8, pp. $1-5,2010$

[10] N. Bahadur, K. Jain, A. K. Srivastavaa, R. Govinda, D. Haranatha, and M. S. Dulat, "Effect of nominal doping of $\mathrm{Ag}$ and $\mathrm{Ni}$ on the crystalline structure and photo-catalytic properties of mesoporous titania," Materials Chemistry and Physics, vol. 124, no. 1, pp. 600-608, 2010.

[11] Y.-H. Peng, G.-F. Huang, and W.-Q. Huang, "Visible-light absorption and photocatalytic activity of Cr-doped $\mathrm{TiO}_{2}$ nanocrystal films," Advanced Powder Technology, vol. 23, no. 1, pp. 8-12, 2012. 
[12] K. Soutsas, V. Karayannis, I. Poulios et al., "Decolorization and degradation of reactive azo dyes via heterogeneous photocatalytic processes," Desalination, vol. 250, no. 1, pp. 345-350, 2010.

[13] Y. Li, J. Chen, J. Liu, M. Ma, W. Chen, and L. Li, "Activated carbon supported $\mathrm{TiO}_{2}$-photocatalysis doped with Fe ions fo continuous treatment of dye wastewater in a dynamic reactor," Journal of Environmental Sciences, vol. 22, no. 8, pp. 1290-1296, 2010.

[14] R. van Grieken, J. Marugán, C. Sordo, P. Martínez, and C. Pablos, "Photocatalytic inactivation of bacteria in water using suspended and immobilized silver-TiO $\mathrm{Ti}_{2}$, Applied Catalysis B: Environmental, vol. 93, no. 1-2, pp. 112-118, 2009.

[15] E. M. Hernández-Rodríguez, P. Acosta-Mora, J. MéndezRamos et al., "Prospective use of the 3D printing technology for the microstructural engineering of solid oxide fuel cell components," Boletin de la Sociedad Espanola de Ceramica y Vidrio, vol. 53, no. 5, pp. 213-216, 2014.

[16] J. C. Ruiz-Morales, D. Marrero-López, J. Canales-Vázquez, and J. T. S. Irvine, "Symmetric and reversible solid oxide fuel cells," RSC Advances, vol. 1, no. 8, pp. 1403-1414, 2011.

[17] J. C. Ruiz-Morales, A. Taranc, J. Canales-Vázquez et al., “Three dimensional printing of components and functional devices for energy and environmental applications," Energy \& Environmental Science, vol. 10, pp. 846-859, 2017.

[18] A. Cybulsky and J. A. Moulin, Structurated Catalysts and Reactors, Marcell and Dekker, Inc, 1998.

[19] B. Utela, D. Storti, R. Anderson, and M. Ganter, "A review of process development steps for new material systems in three dimensional printing (3DP)," Journal of Manufacturing Processes, vol. 10, no. 2, pp. 96-104, 2008.

[20] M. E. Borges, D. M. García, T. Hernández, J. C. Ruiz-Morales, and P. Esparza, "Supported photocatalyst for removal of emerging contaminants from wastewater in a continuous packed-bed photoreactor configuration," Catalysts, vol. 5, no. 1, pp. 77-87, 2015.

[21] Z. Zhou, C. A. Mitchell, F. J. Buchanan, and N. J. Dunne, "Effects of heat treatment on the mechanical and degradation properties of 3D-printed calcium-sulphate-based scaffolds," ISRN Biomaterials, vol. 2013, 10 pages, 2013.

[22] https://www.tinkercad.com/. 

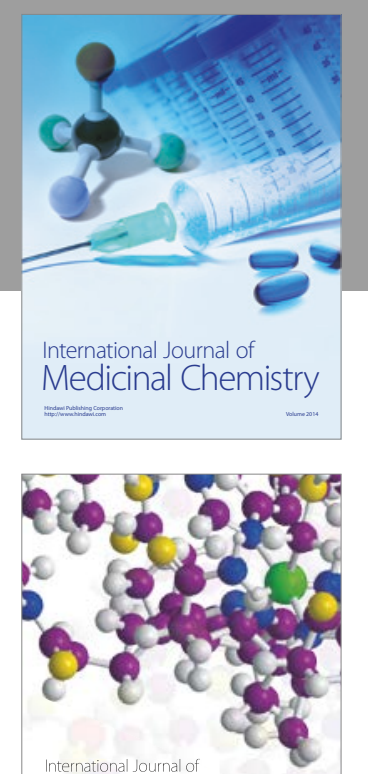

Carbohydrate Chemistry

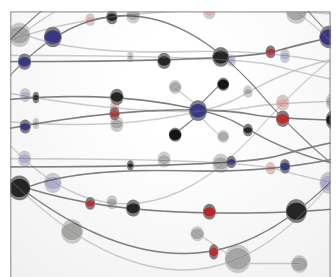

The Scientific World Journal
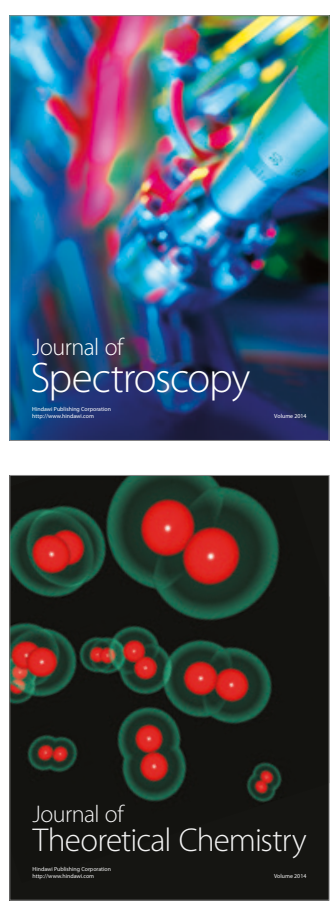
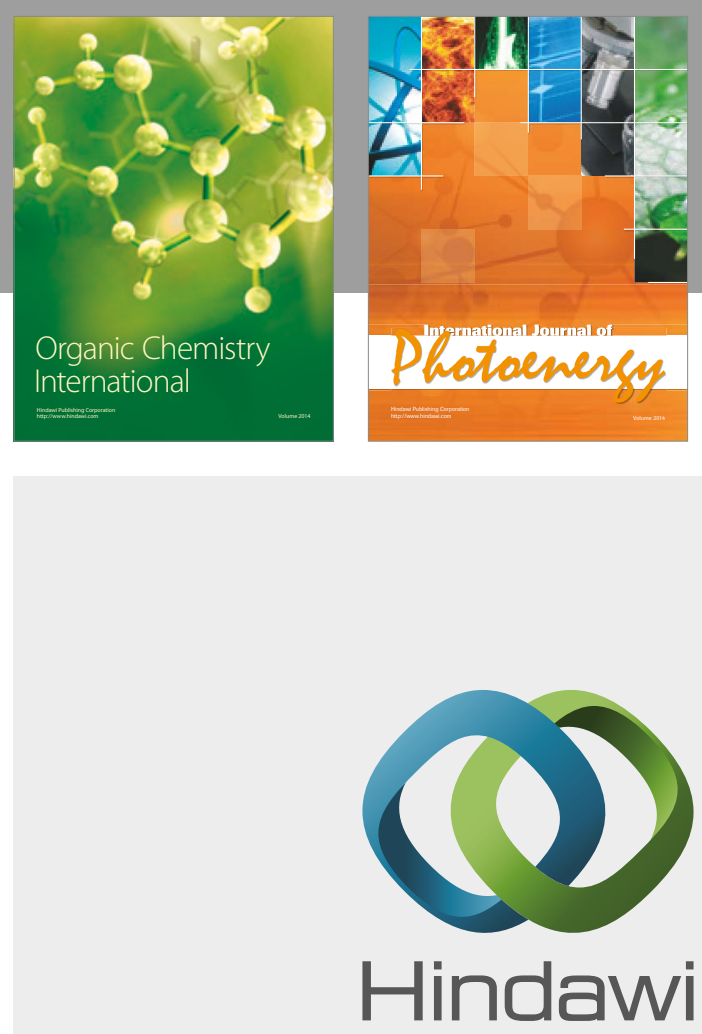

Submit your manuscripts at

https://www.hindawi.com

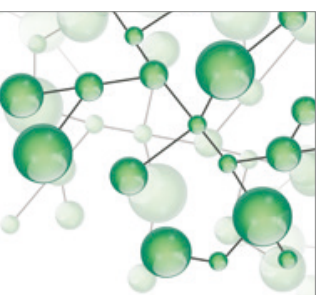

International Journal of

Inorganic Chemistry

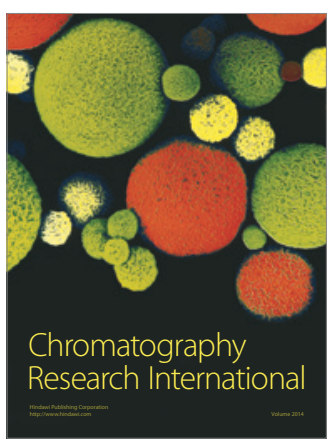

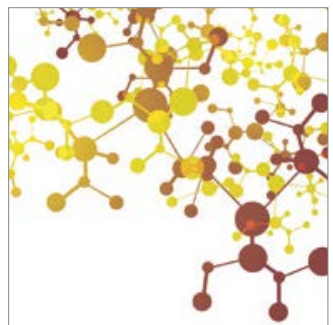

Applied Chemistry
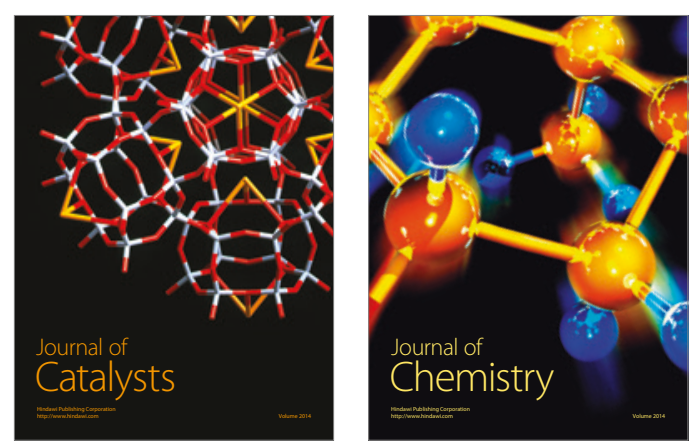
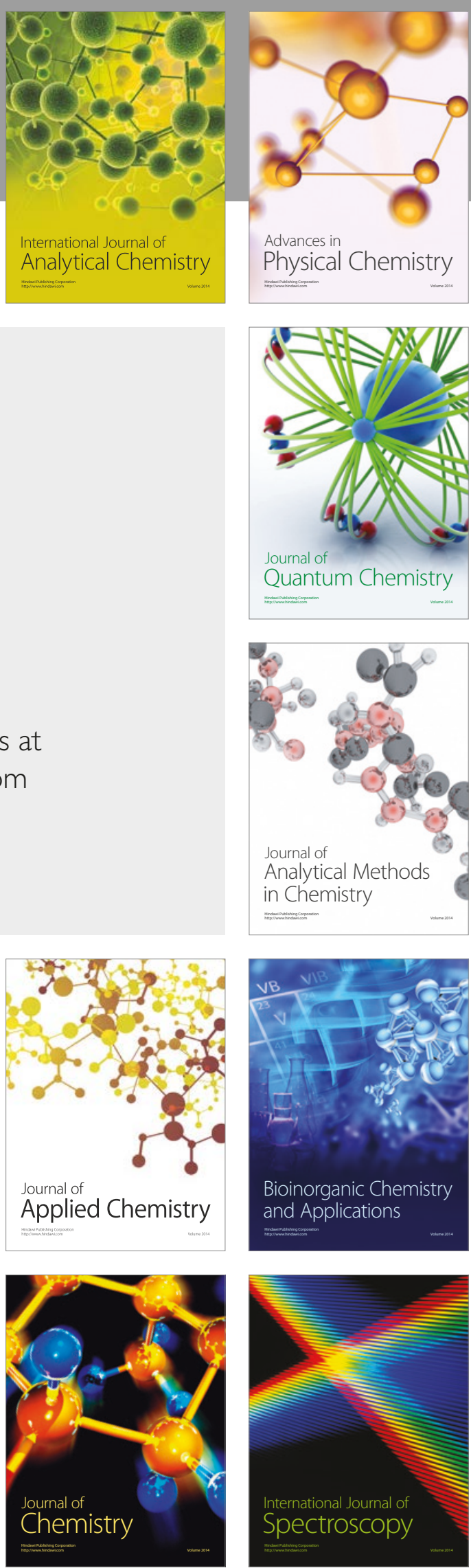